\title{
Pleomorphic Hepatocellular Carcinoma
}

National Cancer Institute

\section{Source}

National Cancer Institute. Pleomorphic Hepatocellular Carcinoma. NCI Thesaurus. Code C43625.

A morphologic variant of hepatocellular carcinoma, characterized by the presence of malignant cells which show marked variation in their size and shape. Bizarre mononuclear or multinucleated giant cells are often present. 